\title{
Research Paper \\ The Study of Vowel Space and Formant Structure in Mazani Language
}

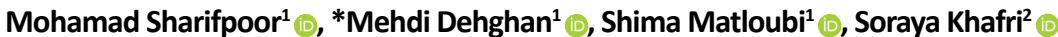

1. Department of Speech Therapy, School of Rehabilitation, Ayatollah Rohani Hospital, Babol University of Medical Sciences, Babol, Iran

2. Department Biostatistics and Epidemiology, School of Public Health, Babol University of Medical Sciences, Babol, Iran.

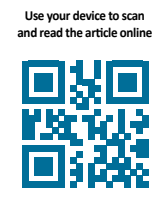

dtat Sharifpoor M, Dehghan M, Matloubi Sh, Khafri S. [The Study of Vowel Space and Formant Structure in Mazani language (Persian)]. Archives of Rehabilitation. 2020; 21(2):272-285. https://doi.org/10.32598/RJ.21.2.2735.1

dol https://doi.org/10.32598/RJ.21.2.2735.1

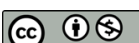

Received: 05 Mar 2018

Accepted: 28 Sep 2019

Available Online: $01 \mathrm{Jul} 2020$

Keywords:

Vowel space, Vowels,

Formant, Persian

language, Mazani

language

\begin{abstract}
Objective One of the parameters showing the correct phonetic and phonological development is the correct and clear articulation of vowels is achieved by changing the shape of vocal cords through altering the height and position of the tongue and the movement of the lips and jaw. The tongue's height and position are the basis of the production and difference of vowels. In other words, the raw sound produced by vocal cords, which has a base frequency, changes and intensifies according to the displacement of organs and vocal tract cavities which makes harmonies from the base sound called formats. These intensified harmonies depend on the shape, size, and material of the cavities, and can affect a person's speech clarity and, consequently, the listeners' perception. Due to such effects and the significant role of vowels space and formants on communicative aspects in each language, they are considered as one of the most important acoustic characteristics of any spoken language. Therefore, determining a scale as a tool to assess vowel errors and speech disorders is necessary. This study aimed to investigate vowel space and formant structure of Mazani language in adults. Materials \& Methods This descriptive-analytical study with a cross-sectional design was conducted on 60 adults ( 30 males and 30 females) with Mazani language aged 18-40 years who were selected randomly and based on the inclusion and exclusion criteria (no history of respiratory diseases, verbal and auditory disorders and having at least 5 years of experience in living in Babol county. After producing the vowels by participants, the first, second, and third formants (F1, F2, and F3) of all 6 vowels were obtained in PRAAT v.6.0 program, and analyzed finally using independent t-test in SPSS v. 18 software.

Results In men, the highest mean value for the base frequency was related to the vowels /i/ and /u/ $(136 \mathrm{~Hz})$, and for F1, F2, and F3, it was related to the vowels $/ æ /(646 \mathrm{~Hz}), / \mathrm{i} /(2182 \mathrm{~Hz})$, and /i/ (2888 Hz), respectively. On the other hand, their lowest mean values were related to the vowels /a/ (124 Hz), /i/ (283 Hz), /a/ (1150 $\mathrm{Hz})$, and /e/ (2629 Hz), respectively. In women, the highest mean values of base frequency, F1, F2 and F3 were related to the vowels /u/ $(222 \mathrm{~Hz}), / æ /(828 \mathrm{~Hz}), / \mathrm{i} /(2346 \mathrm{~Hz})$, and /i/ $(3151 \mathrm{~Hz})$, while the lowest mean values were related to the vowels /æ/ and /e/ $(202 \mathrm{~Hz}), / \mathrm{i} /(364 \mathrm{~Hz}), / \mathrm{a} /(1167 \mathrm{~Hz})$, and /o/ $(2775 \mathrm{~Hz})$, respectively. Conclusion There was difference in formants and vowel space between men and women with Mazani language. The /a/ was the lowest pitch vowel and /i/ and/u/ were the highest pitch the vowels in men, while /æ/ and /e/ were the lowest pitch vowels and $/ \mathrm{u} /$ was the highest pitch vowel in women. Furthermore, the most open, closed, backward and forward vowels were /æ/, /i/, /i/ and /a/, respectively. The /e/ in men and /o/ in women were the most rounded vowels, while the /i/ in both genders was the most unrounded vowel. The results are somewhat different from the results of studies conducted on the production of vowels in standard Persian language. Since the speech clarity and fluency can be affected by the incorrect production of vowels, the results of this study can be used to evaluate and diagnose speech disorders in Mazani language for clinical and research purposes.
\end{abstract}

\section{* Corresponding Author:}

Mehdi Dehghan, MSc

Address: Department of Speech Therapy, School of Rehabilitation, Ayatollah Rohani Hospital, Babol University of Medical Sciences, Babol, Iran. Tel: +98 (912) 5061456

E-Mail: m.dehghan26@gmail.com 


\section{Extended Abstract}

\section{Introduction}

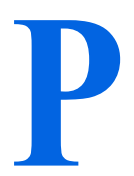

roper and clear production of vowels is one of the parameters for the development of productive and phonological skills in individuals [1]. Vowels are voiced phonemes and depend on the motor delicacy and high motor coordination in the timely completion in the supra-laryngeal pathway and the onset of the vocal fold vibration [2]. The initial sound produced by the vibration of the vocal cords changes according to the movement of the lips and the height and position of the tongue, creating vowels [3-6]. In other words, the primary sound changes and intensifies as a result of any voluntary or involuntary change in the shape and size of the cavities of the vocal cords, and periodic sound harmonies are produced with a certain frequency for each vowel [7]. Each of these sound components and acoustic properties show useful information about the movement and condition of the vocal cords, and is commonly used to indirectly assess the underlying physiological functions in speech motor control. Having a healthy auditory system and natural auditory feedback plays an important role in controlling these components $[8,9]$.

High-energy harmonies are defined as format [6], and the importance of formats is such that the relationships between the first three formats of each vowel help the listener to understand and recognize it. The quality and type of a vowel also depends on its formats $[5,10]$. The main use of formats is in describing vowel errors [3]. They can also be used to compare vowels in different languages and dialects, to accurately study speech disorders such as speech dysfunction, speech apraxia and dysarthria, to study the normal developmental process, and to determine the speech characteristics of deaf people $[12,13]$. Each vowel has several formats; in this study, only the first three formats of vowel are examined. The first structure $(\mathrm{F} 1)$ is related to the height of the tongue; the second (F2) is related to the position of the tongue (front/back movement) and the third format (F3) is related to the shape of the lips (round or wide) $[7,13]$.

The ratios of $\mathrm{F} 2$ to $\mathrm{F} 1$ and $\mathrm{F} 3$ to $\mathrm{F} 1$, during a vowel production, are the same in all people who speak a particular language. In this regard, these ratios play a major role in distinguishing one spoken voice from another [7]. Vowel space is also a graphic image of the vowel area. In other words, it illustrates both the productive and acoustic space of the vowel. That is, it shows the state of vowel production in terms of tongue front/back movement and height, and indicates the ratio of F1/F2. The vowel space is shown by a chart; the vertical axis of this chart shows the tongue height and the horizontal axis shows the tongue movement. In other words, the vertical axis represents F1 and the horizontal axis represents F2 [14].

In the study by Hamdan et al. [15], the formats characteristics of English-spoken Lebanese men for the two vowels /a/ and /i/ were examined. For the vowel /a/, the mean values of F1, F2, F3 were $622.86 \mathrm{~Hz}, 1264 \mathrm{~Hz}$, and 2610 $\mathrm{Hz}$, respectively. For the vowel $/ \mathrm{i} /$, the corresponding values were $378 \mathrm{~Hz}, 2210 \mathrm{~Hz}$, and $2847 \mathrm{~Hz}$, respectively. Mohammadi et al. [16] studied formant structure and vowel space in Persian vowels. Minimum value of F0 in both gender groups was related to $/ \mathfrak{a} /$ and $/ \mathrm{a} /$ and maximum value for $/ \mathrm{i} /$. Maximum and minimum values of F1 were related to /æ/ and /i/; maximum and minimum values of $F 2$ were related to $/ \mathrm{i} /$ and $/ \mathrm{u} /$; and maximum and minimum values of $\mathrm{F} 3$ were related to $/ \mathrm{i} /$ and $/ \mathrm{u} /$.

In Sheikh Sang Tajan et al.'s study [17] on the phonological nature of Persian vowels in CV syllables of spoken speech, minimum and maximum values of $F 1$ was related to $/ \mathrm{i} /$ and $/ \mathrm{a} /$; F2 were related to $/ \mathrm{a} /$ and $/ \mathrm{i} /$; and F3 were related to $/ \mathfrak{x} /$ and $/ \mathrm{i} /$. A noteworthy point in their study was the lack of phonological differentiation of the vowel /o/ in Taleshi speakers, such that all sounds /o/ were pronounced in Taleshi as /u/. Salehi et al. [18] in a study on Formant frequency of Persian vowels, showed that in both genders, the maximum value of F1 was related to the vowel /æ/, and for both F2 and F3 were related to the vowel /i/. However, the lowest value of F1 in men was related to the vowel /i/ and in women to the vowel $/ \mathrm{u}$, and the lowest values of $\mathrm{F} 2$ and F3 in both gender groups were related to the vowel/u/. Mohammadi et al. [19] in a study to compare formant structure of Persian vowels between 50 Persian children aged 7-9 years and 50 adults aged between 18 and 22 years, reported that the range of changes from $\mathrm{F} 2$ to $\mathrm{F} 1$ in boys ranged from 2 in the vowel $/ \mathfrak{x} /$ to $7.7 \mathrm{in}$ the vowel $/ \mathrm{i} /$ and in girls from 1.4 in the vowel /a/ to 8.5 in the vowel $/ \mathrm{i} /$.

Moreover, the range of F3 to F1 variations in boys was from 3.8 in the vowel $/ æ /$ to 11.1 in the vowel $/ \mathrm{u} /$, and in girls from 2.9 in the vowel /æ/ to 10.6 in the vowel $/ \mathrm{i} /$. In all groups, /æ/ was the most open and /i / was the most closed vowel. Furthermore, the vowel /i/ was the first and $/ \mathrm{u} /$ the last vowel. Adults also had lower format frequencies compared to children. In another study by Mohammadi and Mohammadi [20] on Persian vowel formants, the highest

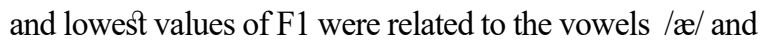
/i/; for F2, were related to the vowels /i/ and /u/; and for F3, were related to the vowels $/ \mathrm{i} / \mathrm{and} / \mathrm{u} /$. 
Therapists often evaluate vowels in a perceptual way and based on their experiences, while with acoustic analysis, it is possible to understand the shape of the vocal cords and how it affects the intensification of the base vowel frequency. The study of the correct production of vowels is not done by perceptual evaluation alone and requires careful laboratory tests. Perceptual evaluations actually involve listening and perceptual judgments that complement the evaluation process along with the study of history. Given the importance of vowels and their format structures and the importance of these components in cognitive and aesthetic aspects, and the fact that the structural pattern and space of vowel are different in different languages, the existence of an index derived from norm speech is useful and necessary for comparison with similar cases in patients' speech. In this regard, a criterion can be provided to be usable in the evaluation and treatment process. Since no study has been done in this field in Mazani language, the present study was conducted with the aim of achieving the characteristics of vowels in Mazani language.

\section{Materials and Methods}

This is a descriptive analytical study with a cross-sectional design conducted on 60 healthy people aged 18-40 years (30 men, 30 women) with Mazani language who were selected using a convenience sampling method from among Employees of Babol University of Medical Sciences, Ayatollah Rouhani Hospital and also patients referred to this hospital. Inclusion criteria were: no history of respiratory disease, speech disorder and impairments related to speech organs, hearing impairment, obvious inflammation of the respiratory and vocal tracts, and being of Mazani descent that have lived in the urban areas of Babol county for at least the last 5 years. The sample size was determined 30 for each gender group according to the formula considering $\mathrm{P}=0.5,95 \%$ confidence interval and error $\mathrm{d}=0.17$.

After selecting the samples, their demographic information were recorded and by explaining the research method, they were asked to produce the vowels in Mazani language $(n=6)$ for 3 to 5 seconds which were given to them in written form. There were asked to pause between each vowel production. They were seated in an upright position and were not allowed to change their position during sound recording. Furthermore, they were asked to keep their mouth distance from the microphone at $20-25 \mathrm{~cm}$. For recording, at least 2 hours had elapsed since the person woke up to reach their daily normal voice. After recording, the examiner stored each of the vowels separately to prepare them for acoustic analysis. The sounds were analyzed using PRAAT sound analysis software and the results were reported in SPSS v. 18 software by descriptive statistics including mean and variance of the formats and analyzed using independent t-test.

\section{Results}

The lowest and highest base frequency values in men were related to the vowel /a/ with a frequency of $124 \mathrm{~Hz}$ and the vowels $/ \mathrm{i} / \mathrm{and} / \mathrm{u} / \mathrm{with}$ a frequency of $136 \mathrm{~Hz}$, respectively. In women, the lowest and highest base frequencies were obtained for the vowels /æ/ and /e/ with a frequency of $202 \mathrm{~Hz}$ and the vowel / $\mathrm{u} /$ with a frequency of 222 $\mathrm{Hz}$. The mean of the lowest and highest F1 values in men was related to the vowel /i/ with a frequency of $283 \mathrm{~Hz}$ and

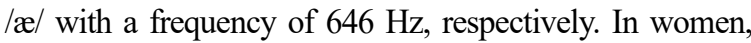
the lowest and highest mean values of $\mathrm{F} 1$ were related to these vowels, ie /i/ with a frequency of $364 \mathrm{~Hz}$ and /æ/ with a frequency of $828 \mathrm{~Hz}$. In comparing to the $\mathrm{F} 1$ values of all vowels between women and men, women had significantly higher F1 values than men, except for the two vowels $/ \mathrm{u} /$ and $/ \mathrm{o} /(\mathrm{P}<0.05)$.

The minimum and maximum mean values of $F 2$ in men were related to the vowel /a/ with a frequency of $1150 \mathrm{~Hz}$ and the vowel /i/ with a frequency of $2182 \mathrm{~Hz}$, respectively. In the female group, similar results were obtained and the lowest and highest mean values of F2 were related to the vowels /a/ and /i/, with frequencies of $1167 \mathrm{~Hz}$ and 2346 $\mathrm{Hz}$, respectively. Comparing the F2 values of all vowels between men and women, women had significantly scores than men $(\mathrm{P}<0.05)$, except for the vowel / $\mathrm{u} /$ where men reported higher $\mathrm{F} 2$ values $(\mathrm{P}>0.05)$.

In the F3, the lowest and highest mean values in men were related to the vowels /e/ and /i/ with the frequencies of 2629 and $2888 \mathrm{~Hz}$, while in women, the mean of the lowest and highest $\mathrm{F} 3$ values belonged to the vowels /o/ and /i/ with the frequencies of 2775 and $3151 \mathrm{~Hz}$, respectively. In this format, the mean frequency of all vowels was higher in women than men, but there was a significant difference only in the two vowels $/ \mathrm{i} /$ and $/ \mathrm{e} /(\mathrm{P}<0.05)$; In the /o/ vowel, where the $\mathrm{F} 3$ value was higher in men than in women, the difference between men and women was not significant $(\mathrm{P}>0.05)$.

The highest mean value of F2/F1 ratio in men and women was 7.7 and 6.4 related to the vowel /i/, respectively, while the lowest mean value in men was 2.1 related to the vowels /a/ and $/ \mathfrak{m} /$ and in women as 1.7 related to the vowel $/ \mathrm{a} /$. Moreover, the highest mean value of $\mathrm{F} 3 / \mathrm{F} 1$ ratio in men and women was related to the vowel $/ \mathrm{i} /$ as 10.2 and 8.6 , respectively, while the lowest mean of this ratio in men and women was related to the vowel /æ/ as 4 and 3.3, respectively (Table 1 and 2) (Figure 1 and 2). 
Table 1. Mean values of base frequency, F1, F2, F3, and their ratios in men with Mazani language

\begin{tabular}{|c|c|c|c|c|c|c|c|}
\hline Group & Vowel & Base Frequency & F1 & F2 & F3 & F2/F1 & F3/F1 \\
\hline \multirow{6}{*}{ Men } & a & 124 & 527 & 150 & 2801 & 2.182 & 5.31 \\
\hline & $\mathrm{i}$ & 136 & 283 & 2182 & 2888 & 7.71 & 10.20 \\
\hline & u & 136 & 376 & 1319 & 2883 & 3.5 & 7.66 \\
\hline & $æ$ & 129 & 646 & 1412 & 2632 & 2.185 & 4.07 \\
\hline & e & 131 & 428 & 1880 & 2629 & 4.39 & 6.14 \\
\hline & 0 & 128 & 436 & 1167 & 2795 & 2.67 & 6.41 \\
\hline
\end{tabular}

Rehabilitation

Table 2. Mean values of base frequency, F1, F2, F3, and their ratios in women with Mazani language

\begin{tabular}{|c|c|c|c|c|c|c|c|}
\hline Group & Vowel & Base Frequency & F1 & F2 & F3 & F2/F1 & F3/F1 \\
\hline \multirow{6}{*}{ Women } & a & 209 & 655 & 1167 & 2847 & $78 / 1$ & $34 / 4$ \\
\hline & $\mathrm{i}$ & 203 & 364 & 2346 & 3151 & $49 / 6$ & $65 / 8$ \\
\hline & $\mathrm{u}$ & 222 & 384 & 1290 & 2928 & $35 / 3$ & $62 / 7$ \\
\hline & $æ$ & 202 & 828 & 1638 & 2796 & $97 / 1$ & $37 / 3$ \\
\hline & e & 202 & 491 & 2204 & 2937 & $48 / 4$ & $98 / 5$ \\
\hline & 0 & 204 & 442 & 1177 & 2775 & $66 / 2$ & $27 / 6$ \\
\hline
\end{tabular}

\section{Discussion}

The aim of this study was to determine a normal speech index that can be used to compare and detect vowel errors and speech disorders in Mazani language. According to the results, in men the vowel /a/ had the lowest base frequency and the vowels $/ \mathrm{i} /$ and $/ \mathrm{u} / \mathrm{had}$ the highest base frequency, while in women, the vowels /æ/ and /e/ had the lowest base frequency and the vowel $/ \mathrm{u} / \mathrm{had}$ the highest base frequency. This is against the results of Mohammadi et al. (2011) since they reported that, in both men and women, the vowels /æ/ and /a/ had the lowest base frequency and the vowel/i/ had the highest base frequency. This discrepancy indicates the difference in acoustic characteristics of Mazani, Kurdish and Persian languages.

The highest and lowest F1 values of men and women in the present study were related to the vowels $/ æ /$ and $/ \mathrm{i} /$, respectively, and the highest value of F2 in both groups belonged to the vowel $/ \mathrm{i} /$. This is consistent with the results of Mohammadi et al. (2011), Mohammadi and Mohammadi
(2003), and Salehi et al. (2008). However, the lowest value of F2 in both gender groups of this study was related to the vowel /a/ which is not in agreement with any studies conducted in Iran. In most studies, the lowest value of F2 was obtained in the vowel $/ \mathrm{u} /$. The reason for this difference seems to be the difference in language and acoustic characteristics of the participants. The highest value of F3 in this study in both gender groups belonged to the vowel /i/, which is consistent with the results of all similar studies conducted in Iran. The lowest levels of F3 were different in men and women in this study; the lowest value in men belonged to the vowel /e/ and in women to the vowel / $\mathrm{o} /$. In other studies, it was related to $/ \mathrm{u} /$ except in Mohammadi et al. (2008)'s study, where the lowest F3 value in men was related to / $\mathrm{o} /$ and in women to /a/. Therefore, linguistic factors can be considered influential in this difference between this study and other studies.

The shape and size of the vocal cords in the production of vowels affect the resonant frequencies or vowel formats. Lowering the tongue makes the space in front of the tongue 


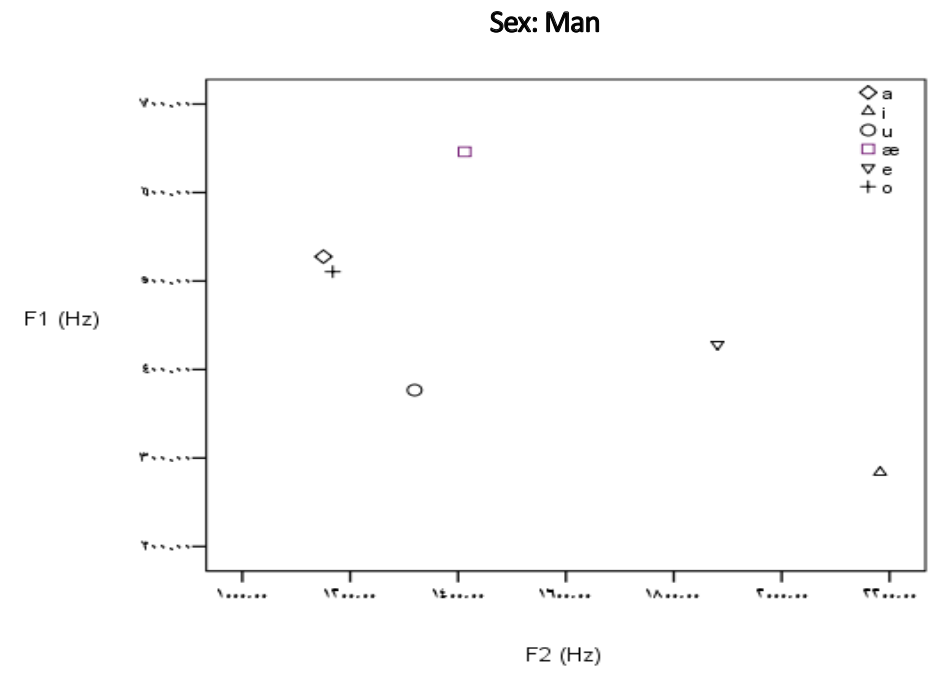

Figure 1. Vowel space chart in men with Mazani language

Archives of
Rehabilitation

larger and thus decreases the resonant frequency, while the space behind the tongue becomes somewhat smaller and leads to an increase in the resonant frequency. In fact, F1 is inversely related to the height of the tongue, meaning that as the height of the tongue decreases, F1 increases. Thus, F1 is expected to be higher in open vowels and lower in closed vowels. In the chart, the vowel space is plotted in the vertical axis F1 and in the horizontal axis F2, where the arrangement of the vowels in the vertical axis indicates how open and closed they are, and their arrangement in the horizontal axis indicates their position in the back or front. According to the vowel space chart obtained in the present study, the lowest and highest tongue height in men and women were recorded in the vowel $/ æ /$ and $/ \mathrm{i} /$, respectively. Therefore, /æ/ was the most open and /i/ was the most closed vowel. Moreover, among the 6 vowels, /i/ was the most backward vowel.
These results are consistent with the results of Mohammadi et al. (2008, 2011), Mohammadi and Mohammadi (2003), and Salehi et al. (2008). However, regarding the most forward vowel, they differ from the results of the present study; in these studies, it was related to the vowel $/ \mathrm{u} /$ while in our study, it was /a/.

The F3 value is related to the shape of the lips and their roundness. In other words, it decreases in round vowels and there is an inverse relationship between its value and the degree of lip roundness; i.e. the wider the lips, the higher the F3 value. In the present study, /i/ was the most unrounded vowel in both men and women, while /e/ and /o/ were the most rounded vowels in men and women, respectively. The result about unrounded vowel is consistent with the results of all similar studies. In most studies, $/ \mathrm{u} /$ was the roundest

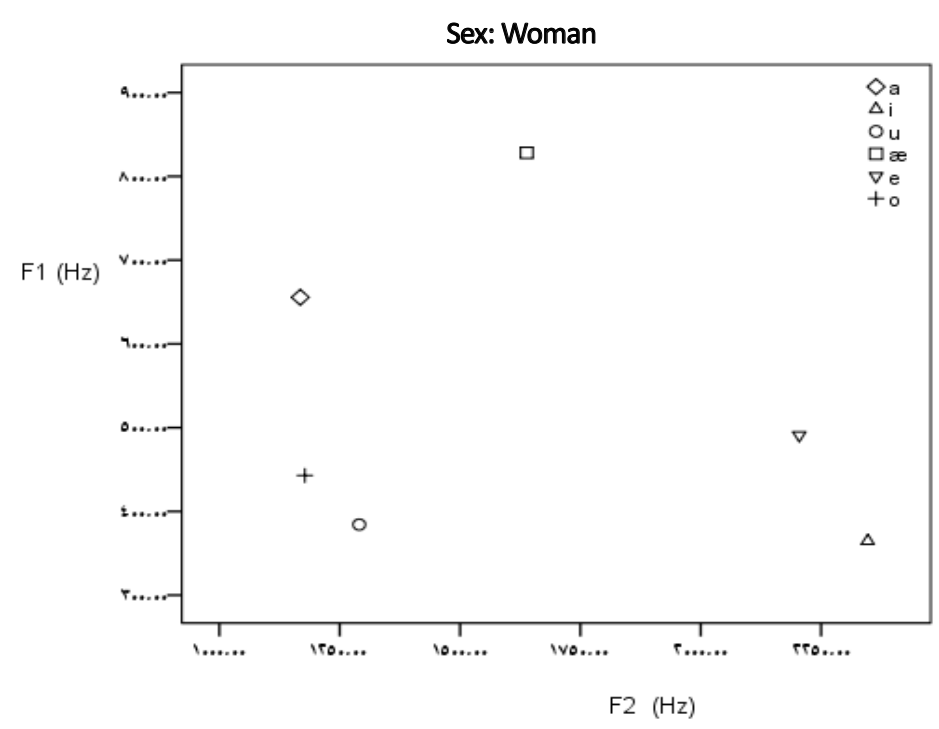

Figure 2. Vowel space chart in women with Mazani language 
vowel. Only in the study by Mohammadi et al. (2008), /o/ was the most rounded vowel. The reason for this difference seems to be the difference in language and acoustic characteristics of the participants.

In the present study, the highest mean value of F2/F1 ratio in men and women was related to $/ \mathrm{i} /$, while the lowest mean value in men was related to $/ \mathrm{a} /$ and $/ \mathfrak{x} /$ vowels and in women was related to vowel $/ \mathrm{a} /$. This is consistent with the results of Salehi et al. (2008). The highest and lowest mean value of $F 3 / F 1$ ratio in men and women was related to /i/ and $/ \mathfrak{x} /$, respectively. This is also consistent with the results of Salehi et al. (2008); however, in their study, the highest mean value in girls was related to $/ \mathrm{u} /$ and the lowest mean value in boys was related to the vowel /a/. This discrepancy may be due to difference in subjects' language.

\section{Conclusion}

Vowel space and format structure in Mazani language is slightly different from other languages and standard Persian language, which can be considered as the main reason for dialectal differences. The results can be of practical importance in diagnosing speech disorders and considering the important role of vowels in speech fluency and clarity for clinical and research purposes.

\section{Ethical Considerations}

\section{Compliance with ethical guidelines}

The participants were informed about the purpose of the research and its implementation stages. They were also assured about the confidentiality of their information and were free to leave the study whenever they wished, and if desired, the research results would be available to them.

Funding

This research did not receive any grant from funding agencies in the public, commercial, or non-profit sectors.

Authors' contributions

All ethical principles are considered in this article.

\section{Conflicts of interest}

The authors would like to thank to the ethics committee of Babol University of Medical Science for their support of this study.

\section{Acknowledgements}

The authors would like to thank the Student Research Committee of Babol University of Medical Sciences for their support. 



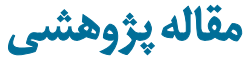 \\ بررسى واكهاى و ساختار سازهاى واكهها در زبان مازندرانى
}

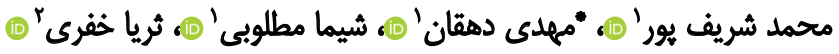

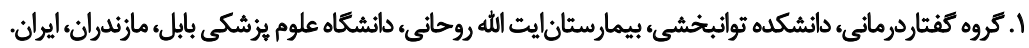

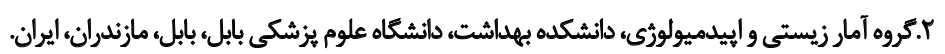

\begin{abstract}
حكיدי

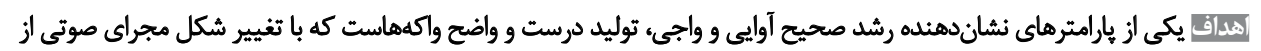

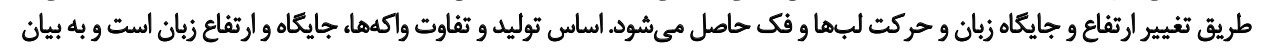

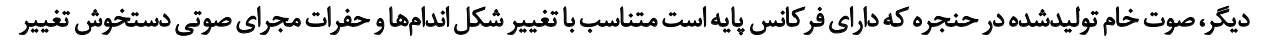

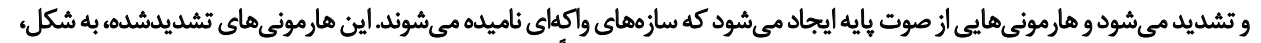

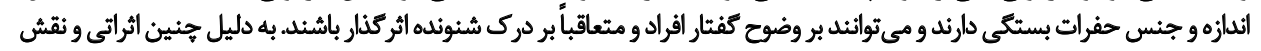

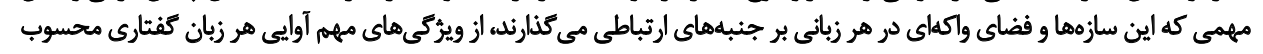

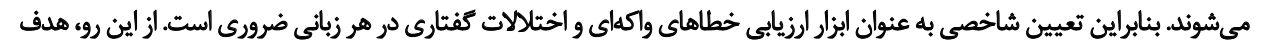

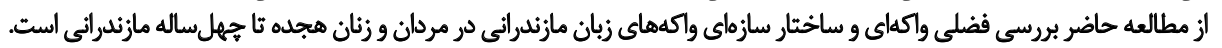

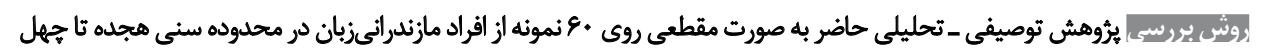

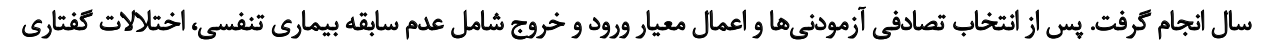

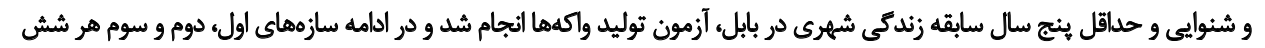

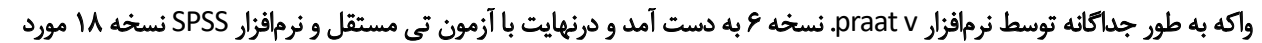
تجزيه وتحليل قرار كرفت.

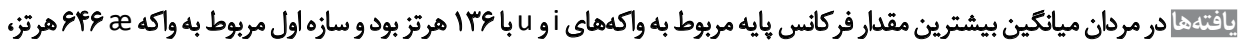

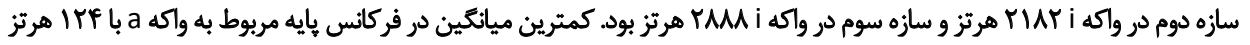

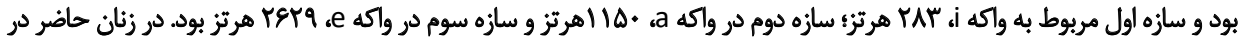

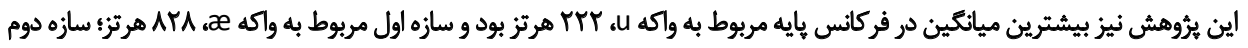

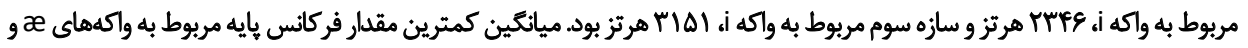

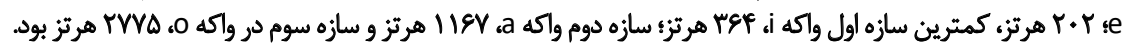

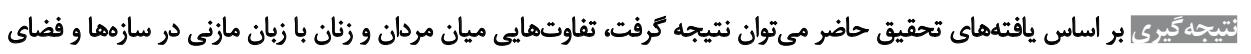

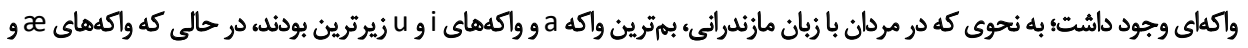

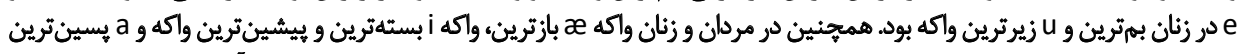

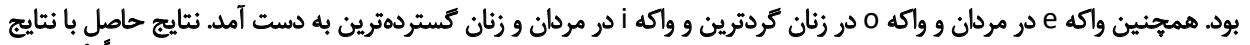

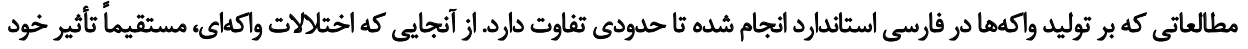

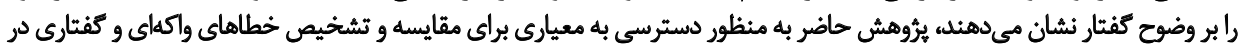

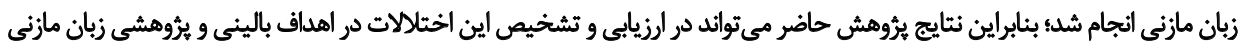
مورد استفاده قرار كيرد.
\end{abstract}

تاريخ دريافت: || اسفند وqجا

تاريخ نيذيرش: 9. مهر

كليدوأرهاء:

فضاى واكهاى، سازه، واركه، زبان فارسى، زبان مازئدرانى زيان فار 


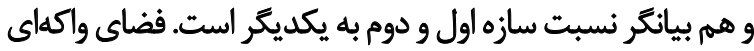

مقلمه

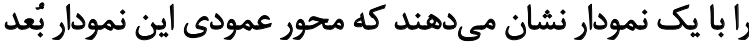

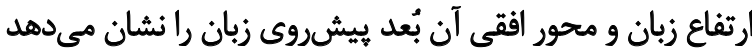

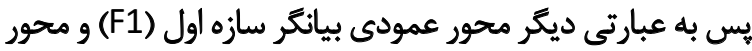

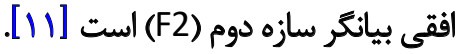

در ادامه به برخى از مطالعات در حوزه بررسى فضاى واكلايى و

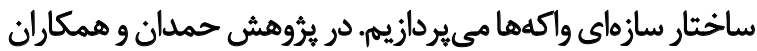

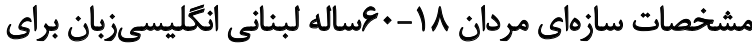

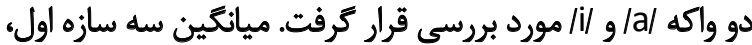

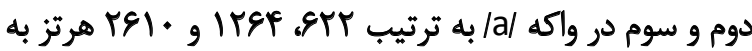

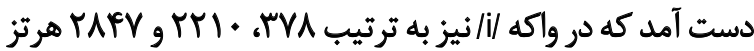

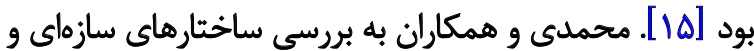

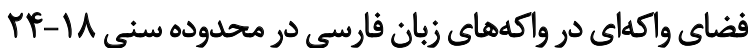

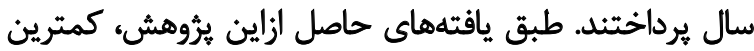

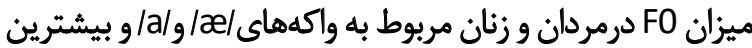

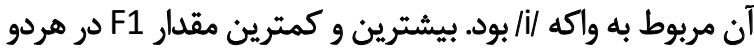

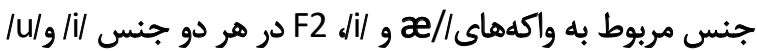

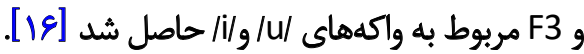

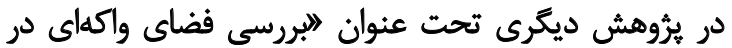

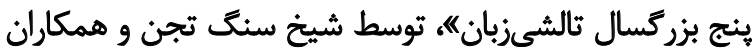

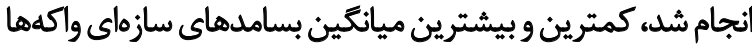

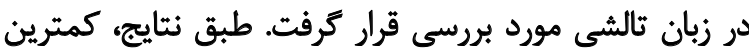

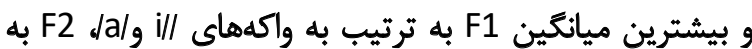

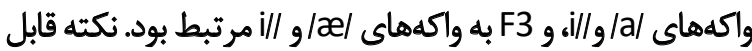

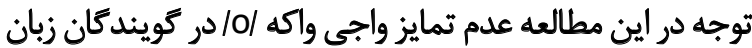

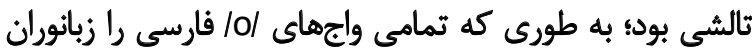

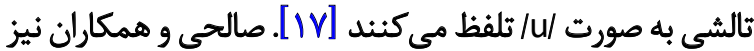

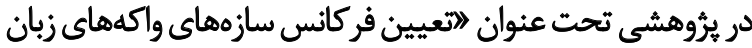

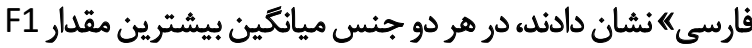

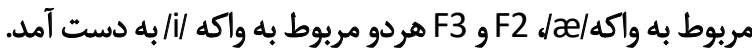

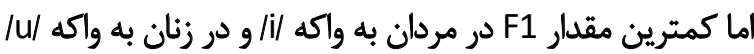

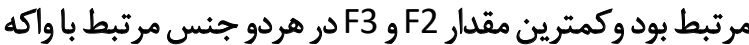

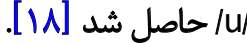

نتايج مطالعه محمدى و همكاران با عنوان "البررسى و مقايسه

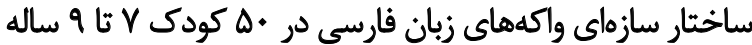

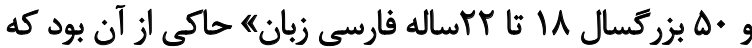

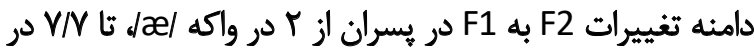

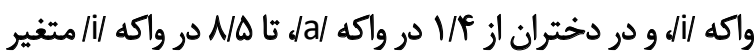

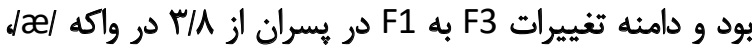

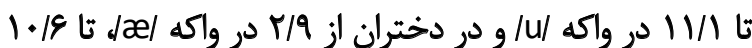

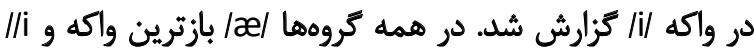

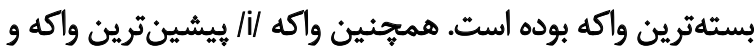
ب/ /U/ بسينترين واكه بود. مردان و زنان نيز به ترثيب در مقايسه

توليد درست و واضح واكهها يكي از يارامترهاى رشد

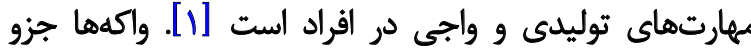

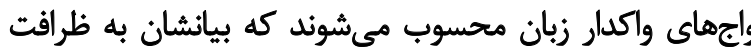

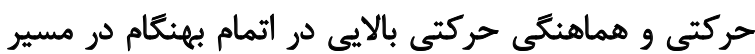

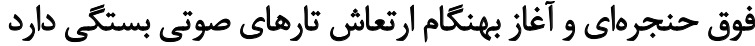

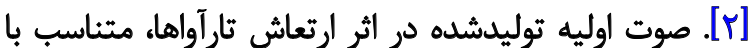

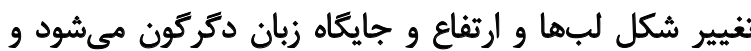

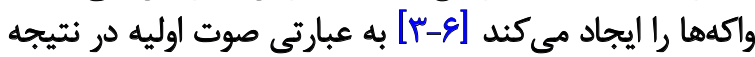

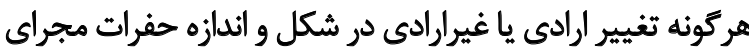

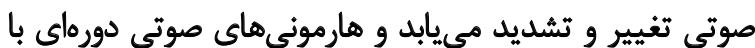

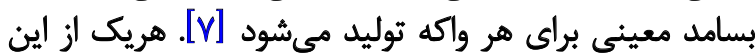

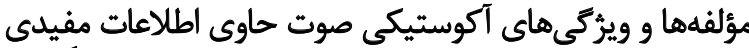

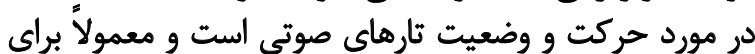

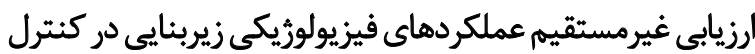

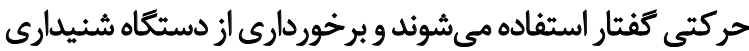

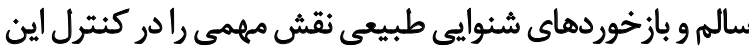

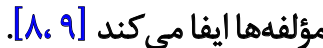

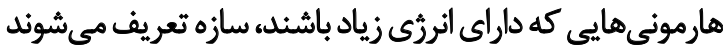

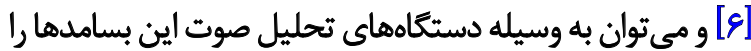

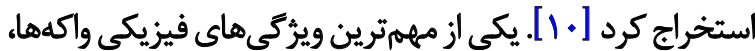

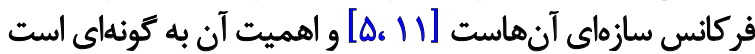

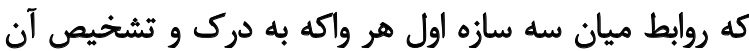

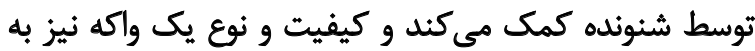

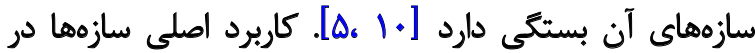

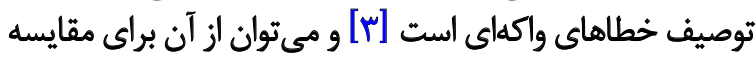

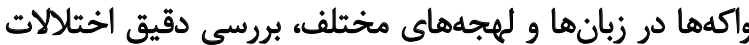

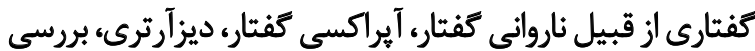

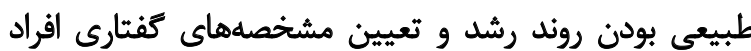

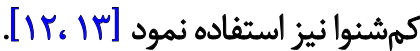
هر واكه داراى جندين سازه است كه دراين بثروهش فقط سه

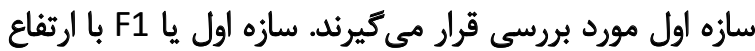

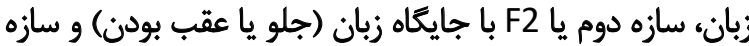

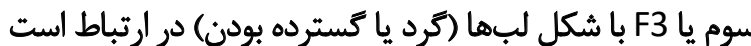

$[\mathrm{V}, \mid \mathrm{F}]$

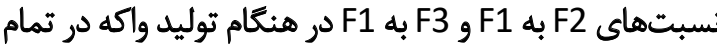

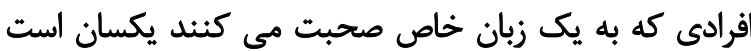

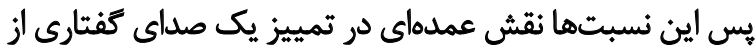

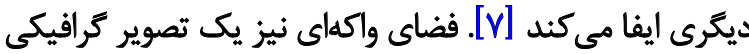

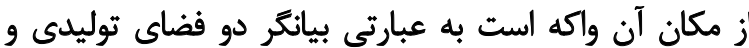

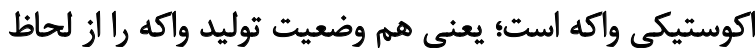
بيشروى و يسروى زبان و هم از لحاظ ارتفاع زبان نشان مي ونهد 
ثانيه توليد كثند و بين هر واكه تا واكه بعدى اندكى مكث كنئن

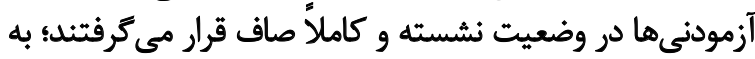

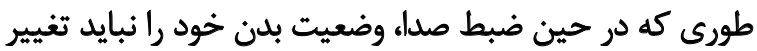

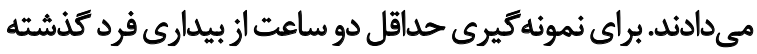

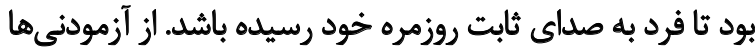

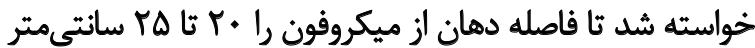

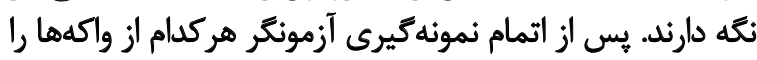

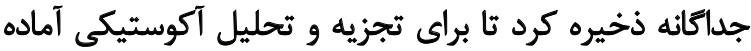

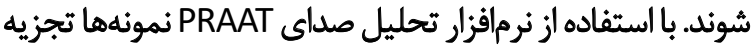

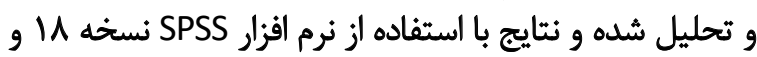

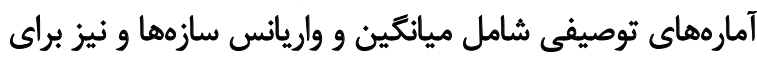

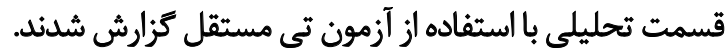

\section{يافتها}

طبق نتايج اين بروهش كمترين و بيشترين مقدار فركانس بايه

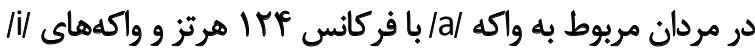

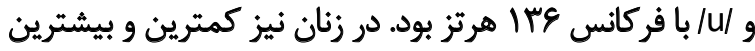

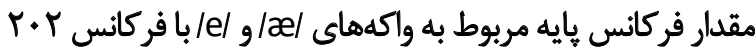

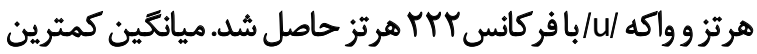

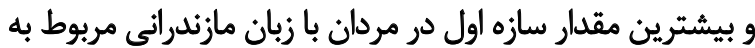

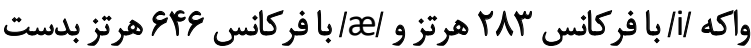

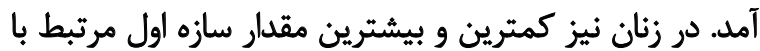

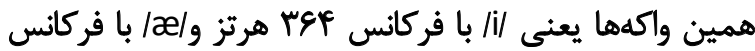

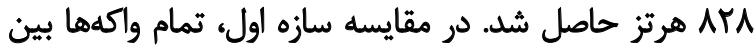

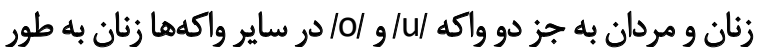

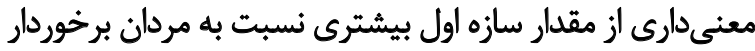

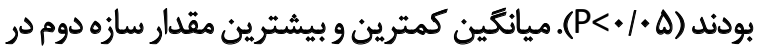

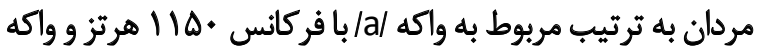
ال با فركانس MIII

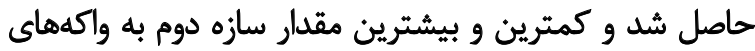

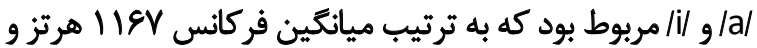

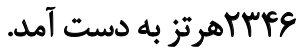

در مقايسه سازه دوم تمام واكهها بين زنان و مردان به جز واكه

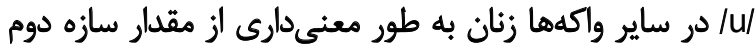

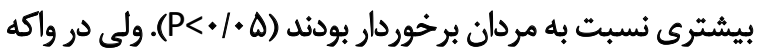

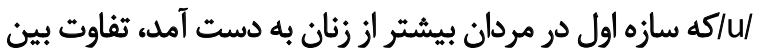

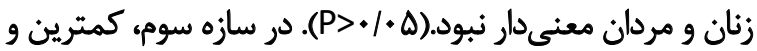

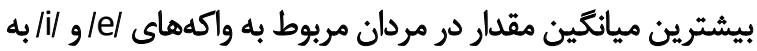

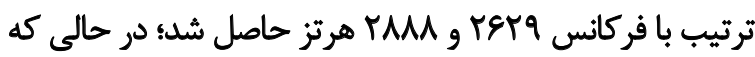

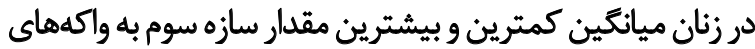

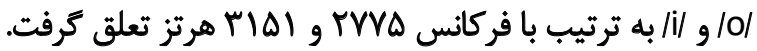

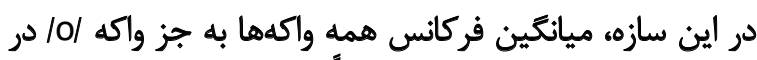

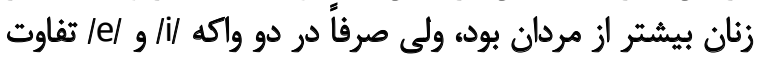

با يسران و دختران بسامدهاي سازماى كمترى داشتئد [19].

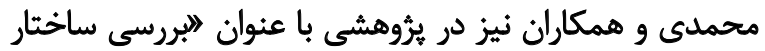

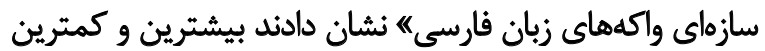

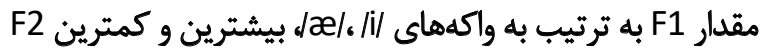

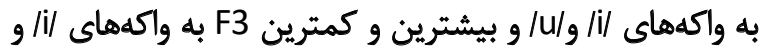

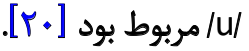

اكثر اوقات ارزيابى درمانكران در خصوص واكهها به صورت

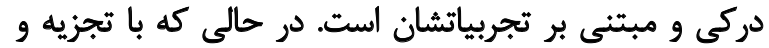

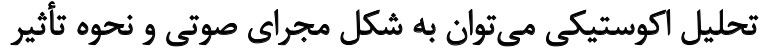

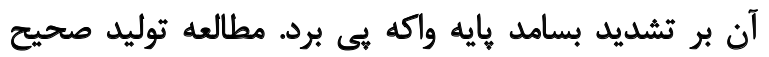

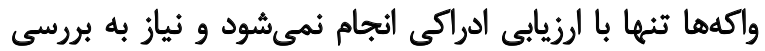

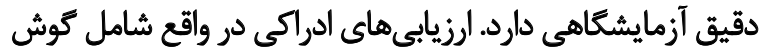

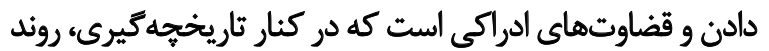

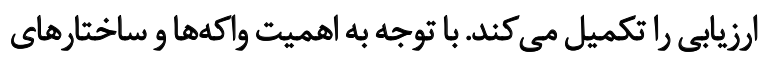

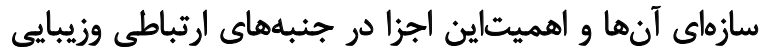

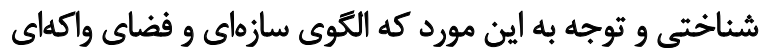

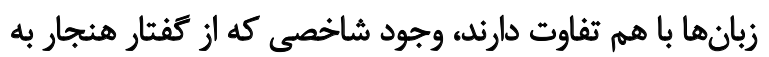

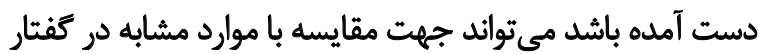

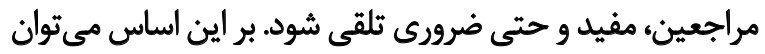

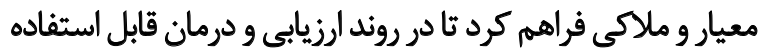

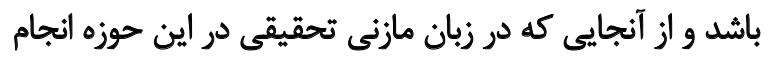

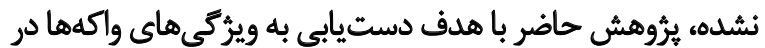

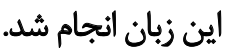
ووش بروسى يُروهش توصيفى ـ تحليلى حاضر به صورت مقطعى در شصت

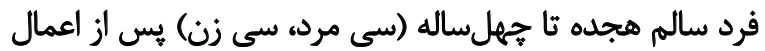

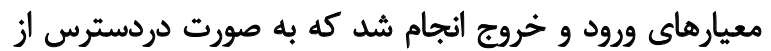

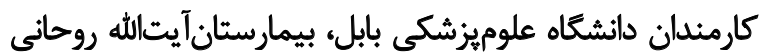

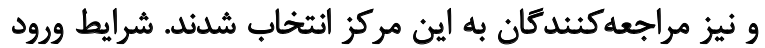

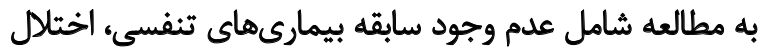

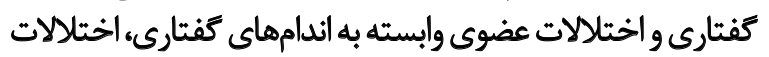

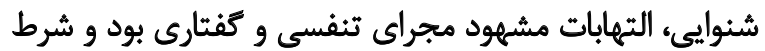

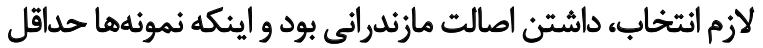

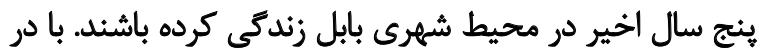

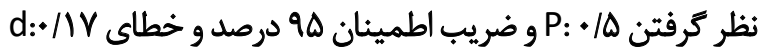

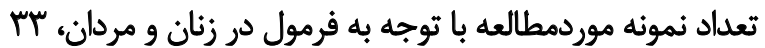

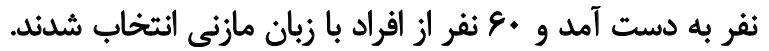

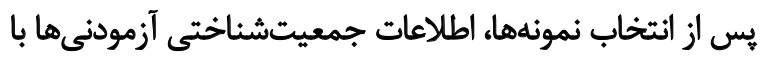

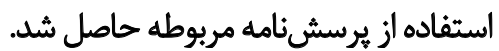
سيس با توضيح روش تحقيق از آنها خواسته شد تا واكههاى

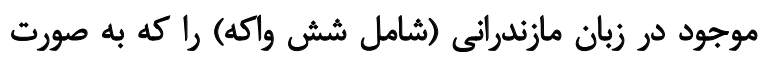

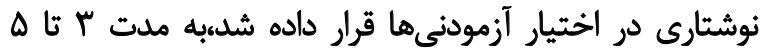


جدول ا. ميانكين فركانس بايه و سازه اول و دوم و سوم واكهها و نسبت آنها در مردان 11|- +fاله با زبان مازندرانى

\begin{tabular}{|c|c|c|c|c|c|c|c|}
\hline نسبت سازه سوم & نسبت سازه دوم & سازه سوم & سازه دوم & سازه اول & فركانس بايه & واكه & كروه \\
\hline$\Delta / r i$ & T/MAT & $r \Lambda+1$ & 10. & DrV & irt & a & \multirow{6}{*}{ مردان } \\
\hline $1 . / 4$. & VM & TMA & TIAT & TAM & ire & $\mathbf{i}$ & \\
\hline VIES & $r / \Delta$ & rMT & $1 \% 19$ & we & ire & $\mathbf{u}$ & \\
\hline$r / . \gamma$ & T/MA & TETr & ifir & ger & Irq & $æ$ & \\
\hline g/N & $p / r q$ & TEYq & $M$. & MA & $m$ & e & \\
\hline $8 / 91$ & r/QV & mas & $119 \mathrm{~V}$ & Pre & IKA & 0 & \\
\hline
\end{tabular}

جدول r. ميانكين فركائ هايه و سازه اول و دوم و سوم واكها و نسبت آنها در زنان 11 - ثاساله با زبان مازندرانى

\begin{tabular}{|c|c|c|c|c|c|c|c|}
\hline نسبت سازه سوم & نسبت سازه دوم & سازه سوم & سازه دوم & سازه اول & فركانس هايه & واكه & كروه \\
\hline$P / M P$ & INA & TAPV & IIFV & SOA & $r \cdot q$ & $\mathbf{a}$ & \multirow{6}{*}{ زئن } \\
\hline NED & e/pq & M|QI & mes & res & $r \cdot r$ & $\mathbf{i}$ & \\
\hline VIRT & H/\% & rqTA & irq. & HAF & MTr & u & \\
\hline$r / m V$ & V/q & rve & IRTA & ATA & $r+r$ & $æ$ & \\
\hline$\Delta / Q \Lambda$ & 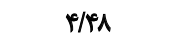 & ratr & $M+\varphi$ & (29) & r.r & e & \\
\hline siry & r/ge & rwa & liw & ner & $r+\varphi$ & 0 & \\
\hline
\end{tabular}

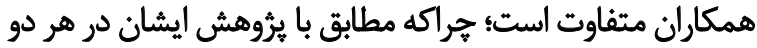

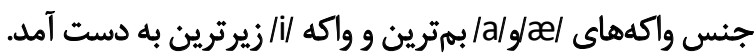

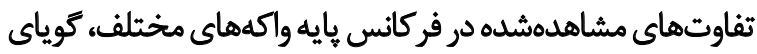

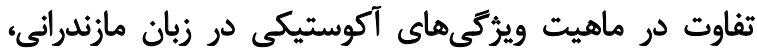

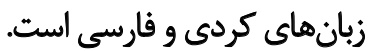

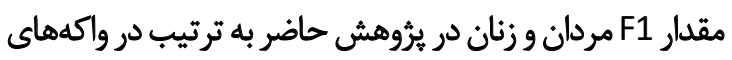

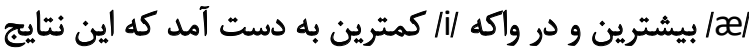

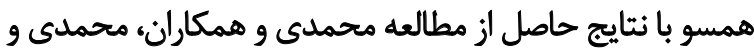

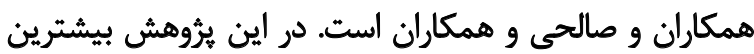

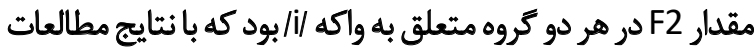

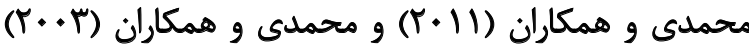

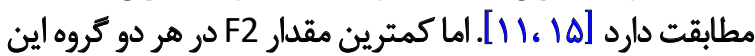

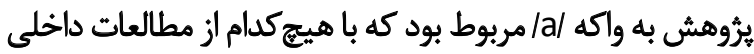

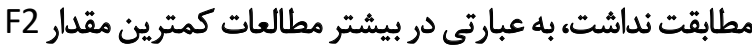

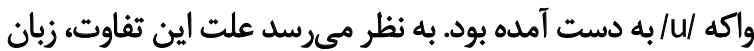

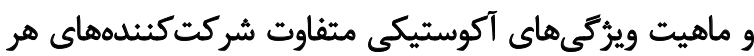

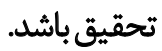

بيشترين مقدار F3 دراين مطالعه در هردو جنس به واكه

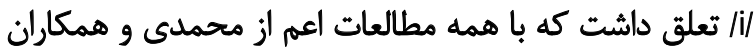

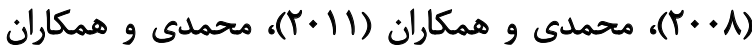

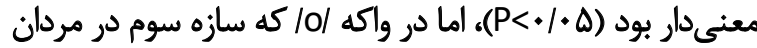

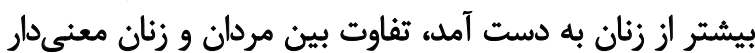

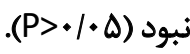

همجنين ميانتين بيشترين مقدار نسبت سازه دوم به اول در

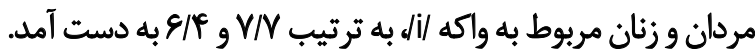

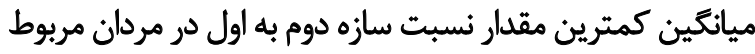

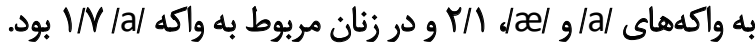

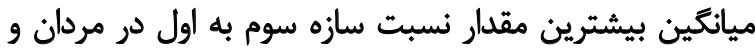

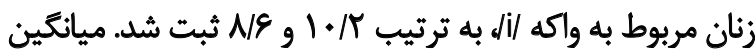

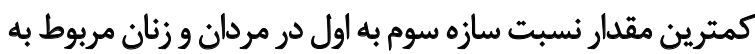

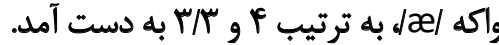

بحث

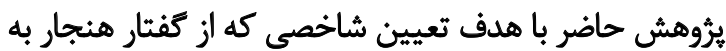

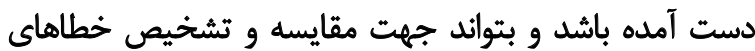

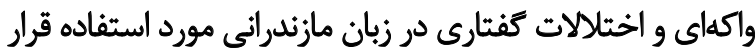

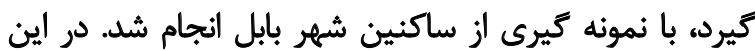

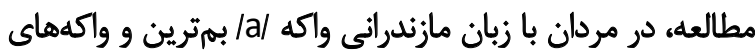

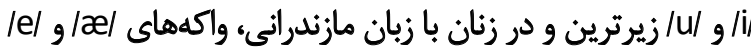

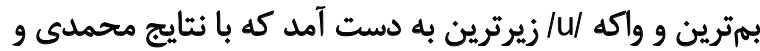




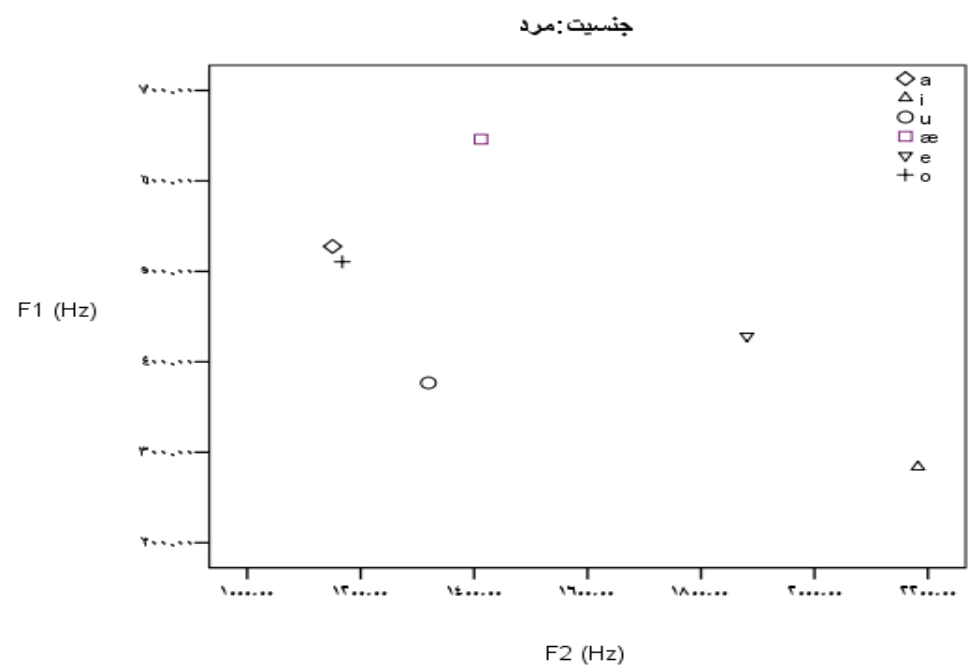

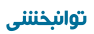

تصوير اـ نمودار فضاي واكهاى در مردان ذبا زبان مازندراني

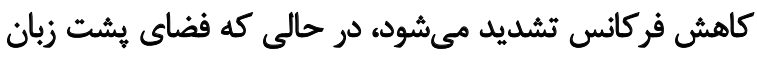

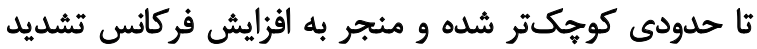

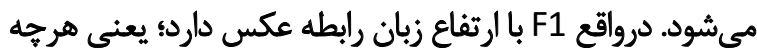

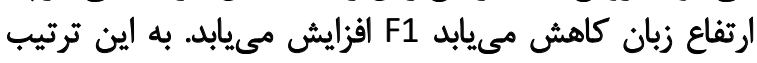

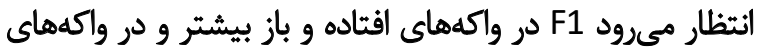

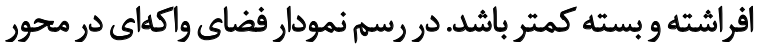

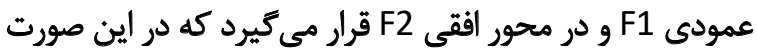

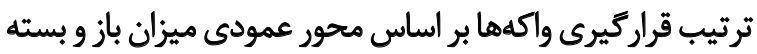

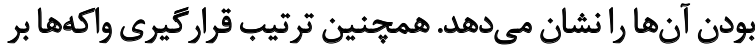

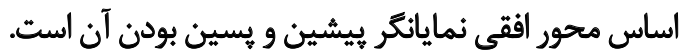
نمودار فضاى واكداى، در واكههاى زنان و مردان مازندرانى، موقعيث توليدى واكهها رادر فضاى دهاي دان ونان ودر مقايسه

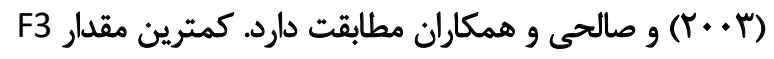

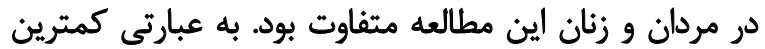

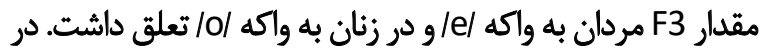

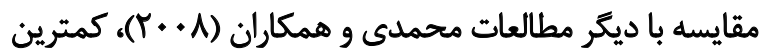

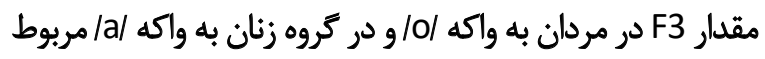

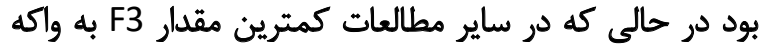

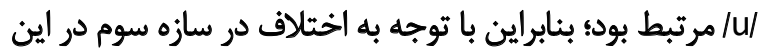

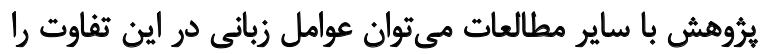

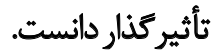
شكل و اندازه مجراي صوتى در توليد واكهها بر فركائسهاي

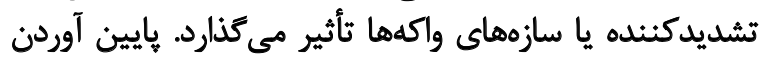
زبان موجب بزركتر شدن فضاى جلوى زبان و در نتيجه

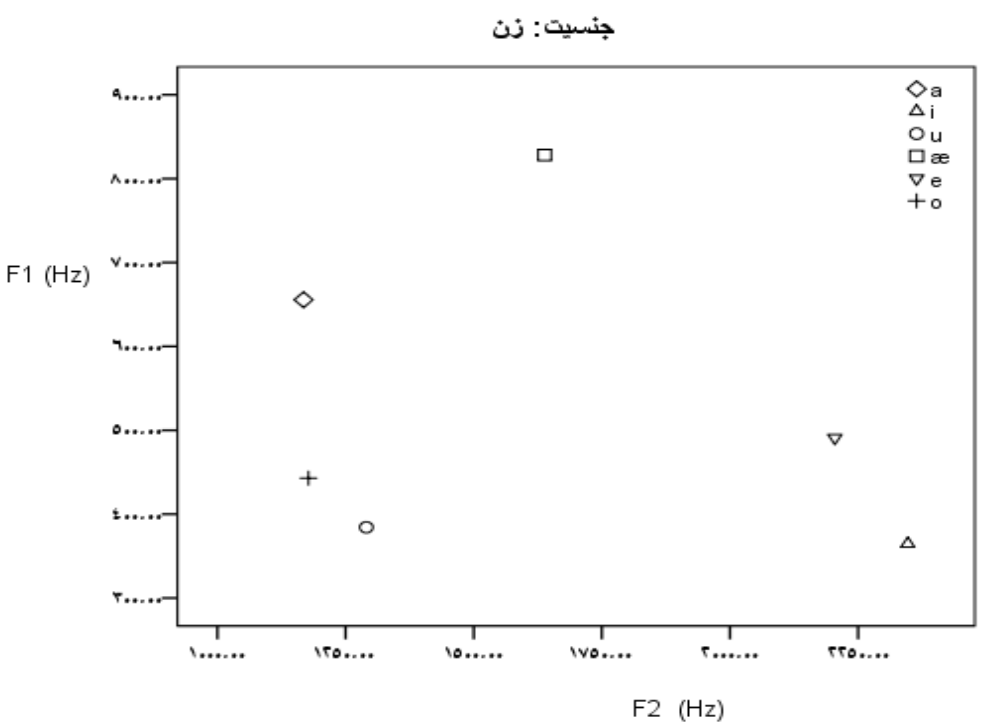


واكهاي و ساختار سازماي در زبان مازندرانى كمى متفاوت از ساير

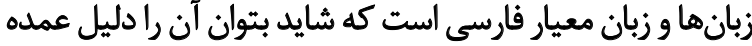

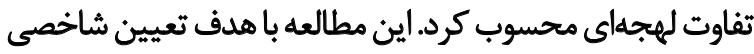

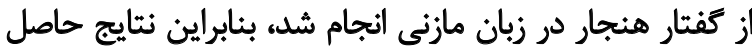

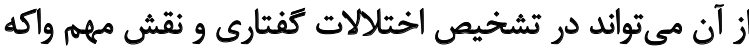

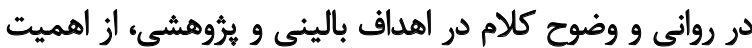
كاربردى و بسزايى برخوردار باشد.

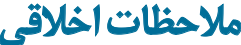

\section{بيروي از اصول اخلاق يُوهش}

به تمامى افرادى كه در يُروهش مشاركت داشتنداين اطمينان

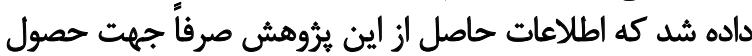

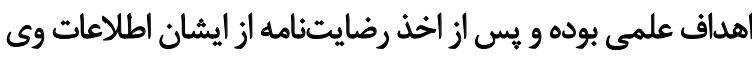

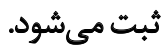

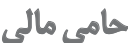

اين مقاله حامى مالى نداشته است.

مشاركت نويسندكًان

تمامسى نويسـندكان در نـعَارش ايـن بايــان نامـه مشـاركت

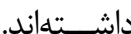

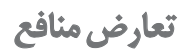

بنا بر اظهار نويسندكان اين مقاله تعارض منافع ندارد.

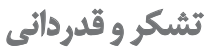

بدين وسيله ازكميته تحقيقات دانشجويى دانشكاه علوميزشكي بابل براى كمكهاى مادى و معنوى قدردانى مىشودي

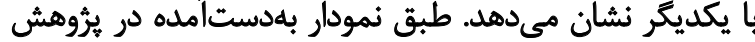

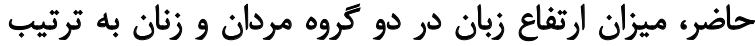

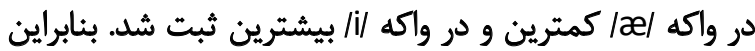

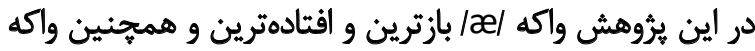

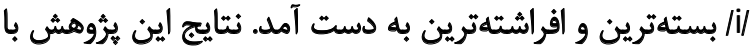

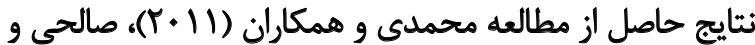

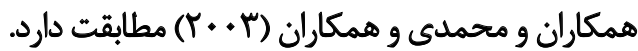

همجنين بر اساس نمودار، در زنان و مردان با زبان مازندرانى در

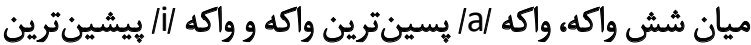

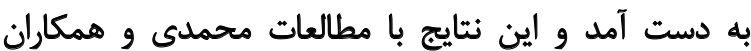
(Y.11)

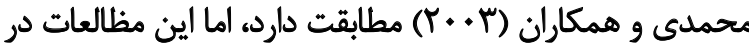

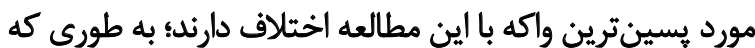

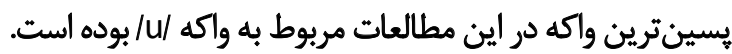
ميزان F3 با شكل لبها و ترد بودن آنها در ارتباط است و

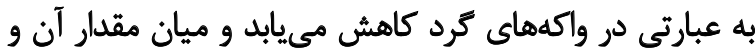

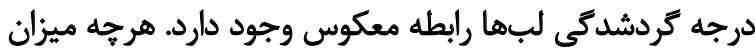

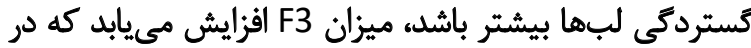

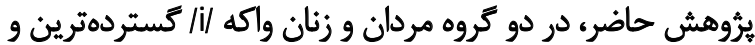

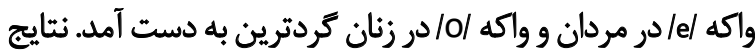

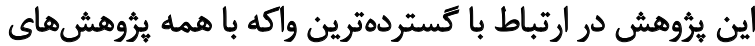

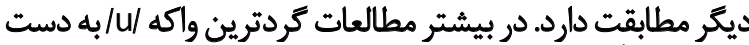

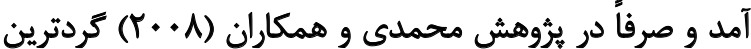

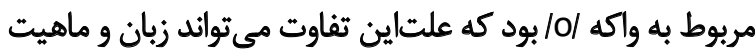

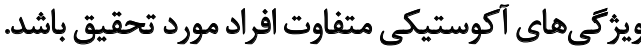

تينجِكَيرى

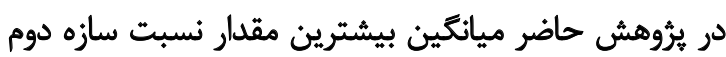

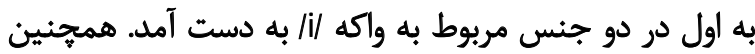

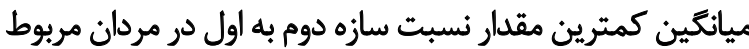

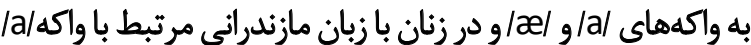
بود. كه اين نتايج با يرؤهش صالحى و همكاران مطابقت داشت ماند

ميانكين بيشترين مقدار نسبت سازه سوم به اول در دو كروه

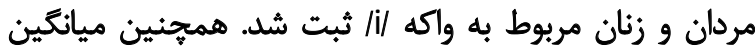

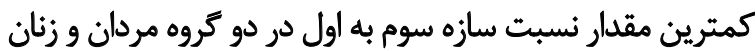

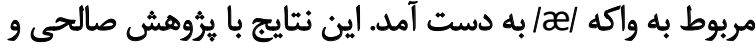

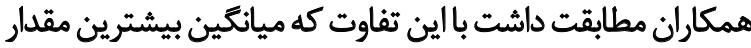

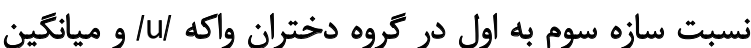

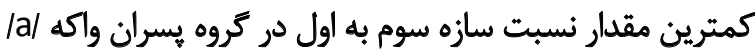

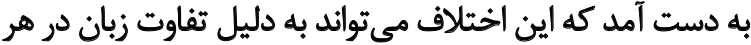

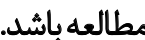
درنهايت همانطور كه از نتايج اين يرؤهش برمىىيد، فضاى 


\section{References}

[1] Zarifian T, Modaresi Y, Dastjerdi M, Salavati M. [Percentage of correct consonants in persian speaking children and its psychometric features (Persian)]. Journal of Exceptional Children. 2014; 13(4) :45-54. http://joec.ir/article-1-194-fa.html

[2] Jahan A. [Voice onset time in Azerbaijani consonants (Persian)]. Journal Of Rehabilitation. 2009; 10(3):19-23. http://rehabilitationj.uswr.ac.ir/article-1-372-fa.html

[3] Johnson K. Acoustic and auditory phonetics. Phonetica. 2004; 61(1):56-8. [DOI:10.1159/000078663]

[4] Holt LL, Lotto AJ. Speech perception as categorization. Attention, Perception, \& Psychophysics, 2010; 72(5):1218-27. [DOI:10.3758/APP.72.5.1218] [PMID] [PMCID]

[5] Yunusova Y, Weismer G, Westbury JR, Lindstrom MJ. Articulatory movements during vowels in speakers with dysarthria and healthy controls. Journal of Speech, Language, and Hearing Research. 2008; 51(3):596-611. [DOI:10.1044/1092-4388(2008/043)]

[6] Taheri Ardali M, Xu Y. Phonetic realization of prosodic focus in Persian. in Speech Prosody. Paper presented at: Speech Prosody. May 2012; Shanghai, China. https://www.researchgate.net/ publication/268437677_Phonetic_Realization_of_Prosodic_Focus_in_Persian

[7] Rezaei N, Salehi A. An introduction to speech sciences (acoustic analysis of speech). Iranian Rehabilitation Journal. 2006; 4(4):514. http://irj.uswr.ac.ir/article-1-3-en.pdf

[8] Jafary N, Yadegari F, Torabinezhad F. [Comparison of duration of persian vowel in children using cochlear implant with normal hearing children (Persian)]. Speech and Language Pathology. 2014;1(1):61-70. https://b2n.ir/742939

[9] Ghayoumi Anaraki Z, Faham M, Bijen Khan M, Izadi F. [Evaluation and comparison of some voice acoustic parameters in patients with true vocal cords' polyps, unilateral paralysis of vocal cords and healthy individuals (Persian)]. Speech and Language Pathology. 2014; 1(2):60-71. https://b2n.ir/125626

[10] Ladefoged P, Johnson K. A course in phonetics. Boston: Cengage Learning; 2014. https://www.amazon.com/Course-Phonetics-Peter-Ladefoged/dp/1285463404

[11] Ladefoged P, Disner SF. Vowels and consonants. Hoboken: Wiley-Blackwell; 2012. https://www.wiley.com/en-us/Vowels+a nd+Consonants $\% 2 C+3$ rd+Edition-p-9781444334296

[12] Baken RJ, Orlikoff RF. Clinical measurement of speech and voice. Boston: Cengage Learning; 2000. https://www. amazon.com/Clinical-Measurement-Speech-Voice-Science/ $\mathrm{dp} / 1565938690$

[13] Shriberg LD, Kent RD. Clinical phonetics. New York City: Pearson International; 2003. https://www.amazon.com/ClinicalPhonetics-Communication-Sciences-Disorders/dp/0137021062

[14] Stemple JC, Thomas Fry L. Voice Therapy: Clinical Studies. San Diego: Plural Publishing; 2000. https://www.amazon.com/ Voice-Therapy-Clinical-Case-Studies/dp/1597563447

[15] Hamdan AL, Ziade G, Al-Zaghal Z, Tabri D, Sinno S, Saade $\mathrm{R}$, et al. Formant characteristics of English-Speaking leba- nese men. The Lebanese Medical Journal. 2015; 63(4):209-12. [DOI:10.12816/0017969] [PMID]

[16] Mohammadi H, Mohammadi R, Torabinezhad F, Rezaei M. Formant structure and vowel space in Persian vowels. Audiology. 2011; 20(2):79-85. https://applications.emro.who.int/imemrf/ Audiology/Audiology_2011_20_2_79_85.pdf

[17] Sheykh Sang Tajan Sh, Bijan Khan M. [The acoustic study of Persian vowels in cv syllables of citation form (Persian)]. Journal of Language Research. 2013; 4(8):97-116. https://jlralzahra. ac.ir/article_1014.html

[18] Salehi F, Bahrami A, Nouri F, Ghanbari H, Baranzehi T. Formant frequency of Persian Vowels in 18-24 years old university students. Journal of Research in Rehabilitation Sciences. 2008. 4(1). http://jrrs.mui.ac.ir/index.php/jrrs/article/view/27/0

[19] Mohammadi O, Pourgharib J. Persian vowel formants an investigation and comparison between Persian children 7-9 years old and persian adult 18-22 years old. 2008: 9(2):105-10. http://koomeshjournal.semums.ac.ir/article-1-49-en.html

[20] Mohammadi R, Mohammadi B. [Studying the persian vowel formants in students of rehabilitation school, Iran University of Medical Sciences (Persian)] [PhD. dissertation]. Tehran: Iran University of Medical Science; 2003. 